\title{
Nurses' Feelings and Perspectives of the COVID-19 Pandemic: A Qualitative Study in a Developing Country
}

\author{
Restuning Widiasih ${ }^{1 *}$, Ermiati Ermiati ${ }^{1}$ D, Etika Emaliyawati ${ }^{2}$ D, Sri Hendrawati ${ }^{3}$ (D) Raini Diah Susanti ${ }^{4}$, Titin Sutini $^{1}$, \\ Citra Windani Mambang Sari ${ }^{4}$ (D) Murtiningsih Murtiningsih ${ }^{5}$ \\ ${ }^{1}$ Department of Maternity Nursing, Faculty of Nursing, Universitas Padjadjaran, Bandung, Indonesia; ${ }^{2}$ Department of Critical \\ Care Nursing, Faculty of Nursing, Universitas Padjadjaran, Bandung, Indonesia; ${ }^{3}$ Department of Pediatric Nursing, Faculty \\ of Nursing, Universitas Padjadjaran, Bandung, Indonesia; ${ }^{4}$ Department of Community Health Nursing, Faculty of Nursing, \\ Universitas Padjadjaran, Bandung, Indonesia; ${ }^{5}$ STIKES Jendral Achmad Yani, Cimahi, Indonesia
}

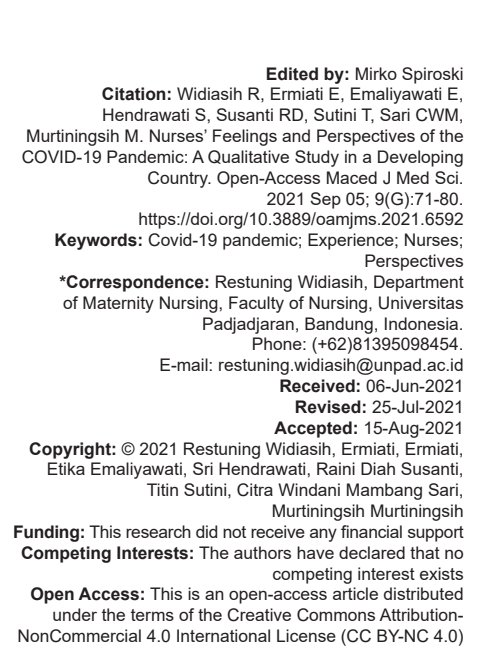

\section{Abstract}

BACKGROUND: Nurses' duties and responsibilities related to the risk of transmitting COVID-19. Studies that explore nurses' feelings and perspectives in providing health services at COVID-19 referral hospitals, especially in developing countries like Indonesia, are limited.

AIM: This study aims to explore nurses' feelings, perceptions, and expectations of the COVID-19 pandemic.

METHODS: This qualitative study applied the qualitative descriptive design that involved 17 nurses from different hospitals in Indonesia. The semi-structured interview gathered their views of COVID-19, and the comparative analysis for interviews technique was chosen to analyze the data.

RESULTS: Three themes emerged from the data analysis. The themes were nurses' express psychologica responses in facing the COVID-19 pandemic such as fear, surrender, panic, and calmness. Other two themes included the COVID 19 pandemic enhances nurses' health awareness and behavior, and the government protect nurses from the COVID-19 transmission and social stigma.

CONCLUSION: The feelings reported dominantly by the nurse, in addition to information about health awareness, behavior, the government's actions, and their expectations. Mental health assistance would be useful to prevent depression in nurses, and the government's comprehensive approaches in dealing with the COVID-19 pandemic would increase the protection and productivity of health workers, including nurses.

\section{Introduction}

The COVID-19 pandemic has spread rapidly from China to the rest of the world, including Indonesia [1]. From March to October 2020, there were 404,048 positive cases of COVID-19 that were confirmed in all provinces of Indonesia [2]. Most cases are in Jakarta (the national capital), East Java, West Java, and Central Java. At present, the recovery rate for COVID-19 patients continues to increase, but there are still new cases every day which fluctuates in number about 3000-4000 cases/day in Indonesia. The Indonesian government has massive efforts to overcome this problem, as the impact of this pandemic is extensive in various aspects, including the health aspect, economy, education, and social.

COVID-19 is a virus transmitted through droplets at a close distance. Droplets that enter through the mouth or nose infect the lungs [3]. Symptoms include fever $>38^{\circ} \mathrm{C}$, cough, shortness of breath from mild to severe, and require hospitalization. The condition of the elderly and a history of diseases such as chronic obstructive pulmonary disease, immune disease, and other chronic diseases would aggravate the COVID-19 [4]. Patients would experience symptoms from mild to severe, critical, and life threatening. These conditions have an impact on the number of patients who die after being diagnosed with COVID-19.

The WHO (2020) releases guidance on COVID-19 management. The Indonesian government is following these guidelines to anticipate the spread of COVID-19, such as mass swabs, activating thermal scanners at 135 entry and exit points of the country, providing health alert cards, information, and health educations to the entire community through various media and cross-sectorial cooperation [5]. The government conducts tracing and tracking to accelerate case tracing and finding, and increase the coverage of laboratory examinations [6]. An indicator of the success in controlling this disease is breaking the chain of transmission by isolating positive cases. Achieving the 
success to deal COVID-19 disease requires an active role from various parties, especially health workers.

Health workers, especially nurses, are at the forefront of caring for COVID-19 patients in hospitals. The government has designated 132 referral hospitals to treat patients with suspected COVID-19 through the Minister of Health Decree Number HK.01.07/ MENKES/169/2020 [7]. Nurses have a huge role and responsibility in managing the COVID-19 patients. Caring of patients at the hospital requires nurses to have direct contact to patients, whether they have been diagnosed with COVID-19 or not. The duties and responsibilities of nurses increase the risk of transmitting COVID-19 to them. Pandemic conditions require nurses to work extra hard so that nurses are at risk of experiencing fatigue, decreasing immunity, increasing the risk of disease transmission to nurses and their family of nurses, and changing nurses' psychological conditions.

The psychological impact is experienced by nurses during the COVID-19 pandemic. Nurses feel anxiety and fear because the number of nurses who died because of infected by COVID-19 continues to increase in the world. It is in line with the condition of Indonesia as a developing country, which has limitations in various aspects, including health facilities, human resources, and funds, thus increasing the risk of contracting COVID-19 to health workers. The multicultural and social conditions of Indonesian society and different levels of understanding about health have an impact on the negative stigma of health workers, including nurses [8]. Huang et al. (2020) stated that COVID-19 was the source of stress in individuals, and various groups of society, including nurses. Nurses in Anhui, China, have high anxiety and fear regarding the spread of COVID-19 [9]. There were studies on the effects of the COVID-19 pandemic on the mental of health workers, especially in developed countries such as China, Germany, and France [10], [11]. Kinds of research that explore the feelings and perspectives of nurses who provide services at COVID-19 referral hospitals, especially in developing countries like Indonesia, are still limited. This study aims to explore the feelings and perspectives of nurses about health services during the COVID-19 pandemic.

\section{Methods}

\section{Research design}

This qualitative research applied the qualitative descriptive design [12], [13], [14]. This design aims to identify current behavioral attitudes by exploring individual or group experiences [12]. This study explored nurses' views and perspectives of COVID-19 pandemic and health services. This research received ethical approval from the human ethics committee of the School of Health Science UNJANI number: 02/ KEPK/III/2020 on March 30, 2020.

\section{Participants and study settings}

This study involved 17 nurses from public and private hospitals who caring for COVID-19 patients in the provinces of Jakarta, West Java, Central Java, and Sumatra, Indonesia. These provinces are regions with the most COVID-19 cases in Indonesia. Participants were selected using the snowball technique as not all hospitals in Indonesia are referrals for COVID-19 patients. The inclusion criteria of participants included currently working in hospital setting with COVID-19 services and minimum 5 years working experience in hospital services. Researchers focus on data saturation and the meaning of the information provided by nurses related to the purposes of the study.

\section{Data collection}

The interviews were conducted in MarchJune 2020. The data were collected using semistructured interview guidelines. The interview is an effective method for exploring human behavior and perspectives [15]. Interviews explored nurses' feelings regarding the COVID-19 pandemic, individual preparations, anticipations to prevent contracting the disease, experiences of dealing with previous pandemics, nurses' perspectives on COVID-19 services, and nurses' expectations regarding COVID-19 services. Interviews were conducted by the principal investigator and three other researchers. The interview did for 30-45 min through telephone $(n=15)$, online applications through Zoom app $(n=1)$, and face-to-face interview $(n=1)$. The principles of COVID-19 prevention were carried out in direct interviews, such as maintaining distance and wearing masks. Explanation of the study and informed consent was done before the interview. Participation in this study was voluntary, and participants could refuse to answer questions that they do not want to answer.

\section{Data analysis}

Four stages of data analysis were applied based on the comparative analysis for interviews technique [16]. The first stage, the researcher and the team read transcribe at least 5 times, made notes, determined the meaning unit, wrote down the data meaning units, and matched the data with the questions. The second stage used NVivo software to organize meaning units according to groups of subcategories and categories. The next was analyzed and linked the data, captured the data message, and determined the research theme. The results of the analysis were, in the form of themes, presented and supplemented with participant 
quotations. Based on the analysis, three main themes were found, including the nurses' express psychological responses in facing the COVID-19 pandemic, the COVID-19 changes in nurses' health awareness and behavior, and government protection felt by nurses.

\section{Trustworthiness}

Credibility, dependability, confirmability, and transferability were components of trustworthiness of this study [17]. Credibility, the principal investigator researcher and the team, reverified the informants to ensure the correctness of the data in the interview guidelines. Dependability was carried out through the research team conducting data inquiries, the researchers verified the research steps starting from the transcribed data, the results of data reduction, and the research process notes. The data analysis was conducted by the research team. Confirmability has done by recording data systematically including field notes. Transferability was carried out by ensuring the criteria of participant and the saturation of data.

\section{Ethics}

The ethical principles were adopted based on the World Medical Association Declaration of Helsinki. The first principle was respect for the person by fully explaining the research and making an informed consent to participants. Participants had full rights to accept or refuse to be research respondents. The researcher guaranteed the confidentiality of participant data, and the research data would only be known by the research team and stored on a computer that could only be accessed by the research team using a password. Participants were coded using the words P1-P17. This study is safe, does not harm, or pose a physical or psychological threat to participants. All participants are treated fairly; all are treated equally, whether nurses from government or private hospitals. This study was received ethical approval number: 02/KEPK/III/2020 on March 30, 2020.

\section{Results} Table 1.

The participants characteristic is described in

Table 1 shows that the number of female nurses $(n=10)$ who participated in this study was more than men nurses $(n=7)$. Most of them worked at public hospitals and only three of them from private hospitals.

The three main themes are illustrated in diagram 1.
Table 1: The characteristic of participants $(n=17)$

\begin{tabular}{lllllll}
\hline No. & $\begin{array}{l}\text { Respondent } \\
\text { code }\end{array}$ & Gender & $\begin{array}{l}\text { Length of } \\
\text { work (years) }\end{array}$ & Education & $\begin{array}{l}\text { IPC } \\
\text { training }\end{array}$ & Hospital types \\
\hline 1 & P1 & F & 7 & $\mathrm{D}$ & Yes & Public Hospital \\
2 & P2 & M & 6 & B & Yes & Public Hospital \\
3 & P3 & F & 5 & B & Yes & Public Hospital \\
4 & P4 & F & 5 & B & Yes & Public Hospital \\
5 & P5 & F & 5 & B & Yes & Public Hospital \\
6 & P6 & F & 7 & B & Yes & Public Hospital \\
7 & P7 & M & 8 & B & Yes & Public Hospital \\
8 & P8 & F & 10 & D & Yes & Public Hospital \\
9 & P9 & M & 8 & D & Yes & Public Hospital \\
10 & P10 & F & 7 & D & Yes & Private hospital \\
11 & P11 & M & 7 & B & Yes & Public Hospital \\
12 & P12 & M & 7 & B & Yes & Public Hospital \\
13 & P13 & F & 8 & M & Yes & Public Hospital \\
14 & P14 & M & 11 & M & Yes & Private hospital \\
15 & P15 & F & 15 & B & Yes & Public Hospital \\
16 & P16 & F & 13 & B & Yes & Private hospital \\
17 & P17 & M & 16 & B & Yes & Public Hospital \\
\hline F: Female, M: Male, D: The Level III Diploma in Nursing, B: Bachelor degree, M: Master degree.
\end{tabular}

The explanation of each theme is as follows:

\section{Theme 1: Nurses' express their psychological responses in facing the COVID-19 pandemic}

Fear versus surrender

The nurse revealed various emotional responses due to the COVID-19 pandemic. Most of them expressed feelings of fear (P1, P3, P6, P7, P12, and P13). Fears occurred, as the number of COVID19 cases is increasing, while the number of patients who recover is also increased. Another cause of fears is that the transmission of COVID-19 to health workers has increased, the number of deaths has increased, including from health workers, limited facilities, and knowledge about COVID-19. Nurses' fear is also due to patient behavior factors, as the following opinion. (P10)

Currently, in my opinion, ma'am, The pandemic, it's not adapting, but scaring me, because in the hospital where I work, yesterday, two patients already diagnosed with positive COVID19 in the previous laboratory test, but the patients hide their health status until we were suspicious, then we did the PCR and checked the Ig and X-rays, the result showed they were positive of COVID-19, they keep silent, even though they had already checked for COVID19 infection ma'am, at Hasan Sadikin Hospital. This condition may occur in hospitals in Indonesia because COVID-19 patients' data have not been online and connected among hospitals. On the other hand, participants said that they surrendered to God Almighty. They realized that they were needed by society, and the most important thing was that they remained alert of COVID-19 risk and transmission, carried out procedures according to the protocol, and provided the best services for public health (P17, P2).

\section{Panic versus calmness}

Panic was reported by several participants (P7, $P 5$, and P11). A nurse felt very alert during the COVID-19 pandemic when her mother had flu at home, without a 


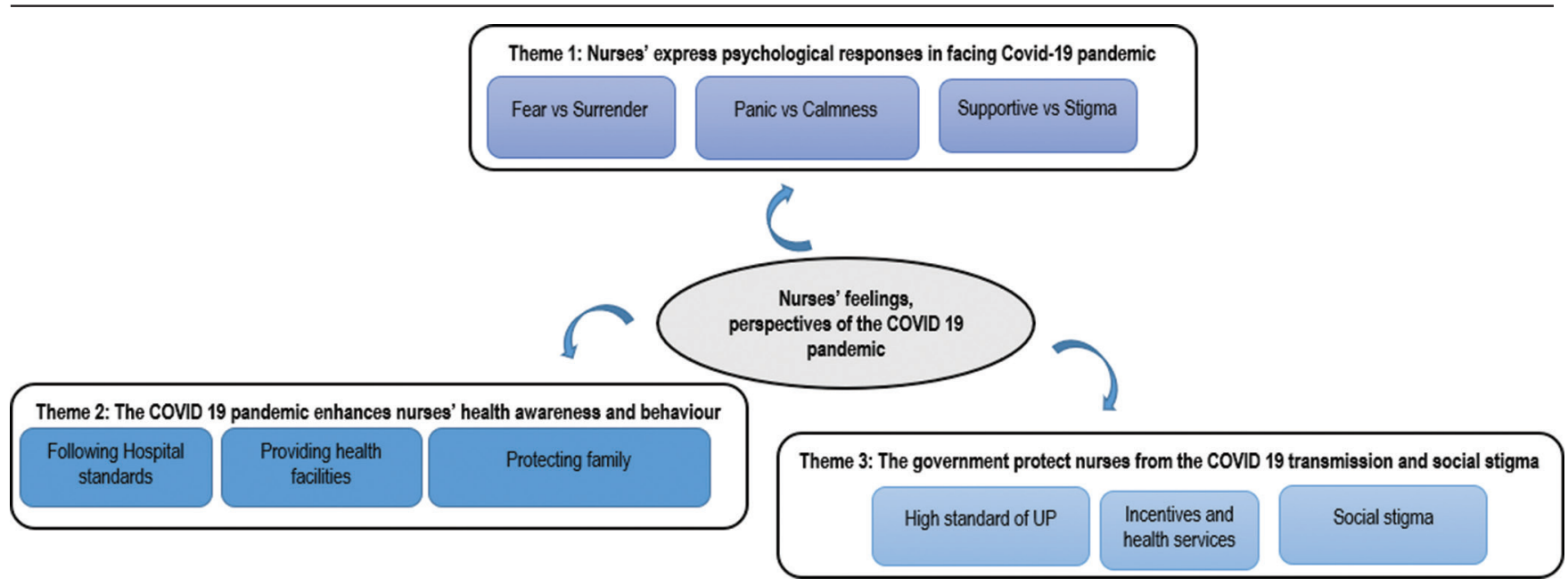

Diagram 1: Finding themes

fever, then she immediately took her mother for X-rays and visited a specialist. It never happened before the pandemic, she felt that this situation made her unable to think appropriately, and all focused on COVID-19. Data about panic were also reported by a senior nurse from a COVID-19 referral hospital, as follows:

Suddenly, there was a change in policy at the hospital, yesterday, it decided that my workplace was chosen as the center of COVID19 referral. My colleagues, coworkers, become upset, anxious, afraid, and so on, many of them are starting to think about resigning from work because they are afraid of COVID-19 transmission. I am a senior, I have responsibilities to motivate and calm them down. (P7)

Panic was also felt by a nurse (P5) whose colleague died because of COVID-19, and she wondered because her friend worked at the VVIP ward, not for a COVID-19 patient. However, nurses at that ward never know that one of the overseas patients was infected by the COVID-19. She described that COVID-19 everywhere in the hospital, and it made her panic, especially as a mother with little kids at home. She fears that if she may get an infection of COVID -19, then no one will take care of her children.

On the other hand, a different opinion was conveyed by nurses who worked in the infectious rooms and had direct contact with COVID-19 patients (P4, P12, P15, andP16) such as IGD and infection hospitals. They said that they felt ready to face this pandemic, physically, and mentally. They had worked and experienced another pandemic previously, and personal protective equipment (PPE) facilities maximum. The regular training was also carried out at the hospital for them. Nurse emotional response varies depending on mental readiness, experience, facilities, and knowledge.

\section{Supportive versus stigma}

Various positive supports are felt by nurses from many components of society (P8, P9, and P10).
This time, health workers, especially nurses, are considered significant in health services. Nurses feel the increase of support and their role is recognized by the community. Society has sent presents, foods, flowers, and PPE facilities.

With the COVID-19 pandemic, I feel that the public cares for health workers. In hospitals, society, and companies either small or big companies, they provide multivitamins, nutritious food, and other gifts for health workers. In the hospital areas, many flowers are received with motivational words, and there are also social movements to support nurses in many media not only nurses but also the family of nurses get support too. (P5)

On the opposite, nurses also had unsupportive experiences from the community (P15 and P12), and they receive unfounded accusations from them, such as the pandemic being a moment to raise money when many other people have been laying off from jobs. For example, health workers have decided the price of a COVID laboratory test, while they also receive incentives because of this pandemic. Mass media information sometimes becomes a stressor for nurses (P7, P8, and P11). There is a fear of stigma in the community that they would transmit the disease because of working in hospitals (P10 and P12). Clear and correct information about the duties of nurses and COVID-19 hospital policies, including the COVID-19 test prices and the process, should be understood by the public so that the negative stigma to nurses would be prevented.

Theme 2: The COVID-19 pandemic enhances nurses' health awareness and behavior procedures

Following the hospital standards of

The nurse revealed various positive changes in health services due to the COVID-19 pandemic, especially behavior and awareness to prevent 
disease transmission. Participants (PI, P2, P3, P5, and $P 8)$ said that health workers are currently aware of the importance of social distance, using PPE, and implementing standard procedures for preventing the transmission of COVID-19. A nurse (P6) stated:

Change, I feel, there are many sinks in the hospital, the patient's family is limited to visiting, there were rules but they can be negotiated, like that. Yes, what's called the health behavior of health workers has changed too, diligently washing hands, before the pandemic, it may be a formality, now it's a necessity, that's all. (P6)

The nurse (P4) who works with a focus on preventing infection in hospitals shared her opinion that during the COVID 19 pandemic, she became more assertive in reminding nurses and other health workers if they did not follow standard infection prevention procedures.

\section{Behavior modifications}

The limited provision of PPE was felt at the beginning of the pandemic, and the referral hospital located far from the capital has limited stock of PPEs, then finally, they wore a raincoat to solve the limitation of PPE, and it became viral on social media (P12). Nurses (P1 and P7) in other districts also reported the same problems of PPEs and hand washing facilities. At present, PPE facilities at COVID-19 referral hospitals are increasing. Nurses (P3, P16, and P17) shared that regional hospitals have provided rooms for COVID-19 patients since the pandemic, although the number of COVID-19 cases is still rarer in Sumatra Province than in Java provinces. In a hospital in Sumatra, all preparations were monitored by the local government and the parliament. The nurse (P4) from a national referral hospital shared the following information;

PPE has been provided and all those who work in the hospital are given information on how to wash hands and use PPE appropriately. So, because this hospital has a specialty service for infectious diseases including COVID-19, it must be used precisely. In the ward, any time something like this situation, they are ready to wear N95 masks. Cleaning services are also trained in standard infection prevention procedures. The hospital has provided laboratory service facilities for patients. First, the patient is required to have an X-ray examination, laboratory check, PCR test, and then the results are sent directly to the center of COVID-19 (PCR test), and the results are received online. $(P 4)$

Nurses (P8 and P10) said that the hospital had established standard operating procedures regarding health service modifications because of the COVID19 pandemic, such as online registration, appointment systems, and home care services. The nurse said that the hospital provides information for visitors, such as flyers about COVID-19 prevention. Flyers were available in many parts of the hospital, as well as hand washing and hand sanitizer facilities.

\section{Protecting family from COVID-19 transmission}

The nurse explains her actions to prevent transmission to the family by modifying the environment and behavior. They said that this action was important because the nurse would be in contact with the family at home. The nurse (P6 and P10) said when she returned home, she entered through the back door and the kitchen then, she went to the bathroom to wash up before meeting her children. Nurses also provide additional vitamins to increase the immunity of their children, as stated by $\mathrm{P} 10$ "For my children, I give Habatussauda (black cumin), kurma, and honey, and other natural vitamins. That is enough." Almost all nurses (P4, P5, P6, P7, P8, P9, $\mathrm{P} 10, \mathrm{P} 12$, and P15) described their main actions to prevent COVID-19 transmission to their families, such as providing food, nutritious drinks, and extra vitamins. Nurses who usually come home immediately hug their families; nowadays, they must be more guarded and avoided. The transformation is felt by nurses (P1, P6, and $\mathrm{P} 10$ ) in the hospital. They perceived people who visit the hospital is limited, may because people must wear a mask as recommended by the government.

Theme 3: The government protects nurses from the COVID-19 transmission and social stigma

This topic reveals the government's efforts to protect health workers, and nurses' expectations of the government during the COVID-19 pandemic.

\section{Providing a high standard of UP}

The hospital provides PPE for each health workers, and nurses expect an increase in the quality and quantity of PPE (P7, P9, P12, and P15).

PPE, thank God, for now, it's still easy to get in my workplace, Ok. But in terms of quality, it needs to be improved, for example, hazmat which is good quality is made from polyester, it is indeed a bit difficult, we are provided with spun-bond material. But we modify it, for example, using two hazmats. So we do various ways to keep it safe, ma'am. (P9)

The same opinion was expressed by nurses who worked in regional and private hospitals. The nurse working in the ER room said that the PPE is available in the hospital, but the nurse had to order first to the logistics department. They asked for details of the patient's conditions, and then, they could conclude whether nurses need the level 3 PPE or No, we should provide accurate data of patients. For nurses who work in private hospitals, PPE is always available. 


\section{Incentives}

The government's attention to nurses provides various forms, either incentives or opportunities to attend training. The media reported incentives for nurses. Nurses who work in the non-COVID-19 room conveyed that incentives paid only for nurses who work in the COVID-19 service room. However, different information was shared by nurses who worked in one of the national referral hospitals, as follows:

The problem is news about incentives money for health workers from the government, seven million per month. So, it looks like nurses are working because they want that incentive. The fact, there is no money until now, but they blame us for the incentive, we keep working even though there is no incentive, thank God we still have a job at this difficult time. So, it makes me a bit uncomfortable, ma'am. Why should it be reported that the government will give money so that the lay people think that health workers get a lot of money because of this epidemic? Their opinion is wrong, the government's money is already running out to buy PPE, no more money for health workers. Some of us, especially non-civil servants' workers, do not get their right to receive incentives for "hari raya" (the Eid Celebration). Then for us, civil servants, the monthly incentive (remuneration money) is reduced because the hospital's income has decreased. (P15)

A nurse who works in a private hospital said there are no incentives for nurses, even though they work extra time and in a high-risk situation of COVID-19 transmission. Incentive policies should be given not only for nurses in public hospitals but also for private hospitals. Delaying in distributing the incentives for health workers would be demotivating them from working.

Each province has different policies related to rewards and incentives. As a result, nurses' welfare may be different. The local government in Central Java Province appreciates nurses by giving the scholarship opportunity for their children. "Yes, my child gets an offer to go to high school for free, other coworkers too" (P6). Other facilities are provided by the hospital for nurses, such as temporary dormitories for on-duty nurses, as an effort in preventing COVID-19 transmission to families (P15).

One of the nurses' expectations for the government is about their access to health services, especially in the workplace. Nurses have to follow the same procedure as other patients when accessing health services, and they feel it is ineffective, for example, they feel sick in the workplace (hospital), and the nurse's house is far from the hospital, so she could not use her health insurance in the workplace, she has to start treatment from the primary health care closest from home.

You can imagine, I work in the capital, and I live in a suburb, when I work and feel sick, I can't get treatment at my workplace, the health insurance rules said, I have to get a referral from the primary health care first. While my condition is weak, I need to process complicate administration stuff. (P 5)

Another expectation is related to the nurse's family welfare and protection. Nurses mostly female that have responsibilities to take care of children or family members based on Indonesian culture. If the family is sick, especially children, it becomes more difficult for them if the child has to be hospitalized in a different hospital from the workplace. It may have an impact on work productivity, as in the pandemic, nurses are at the forefront of COVID-19 patient care.

\section{Social stigma}

Concerns about social stigma were expressed by participants (P12 and P15). They are aware of these risks because they live in diverse communities. In preventing stigma that nurses as a source of transmission of COVID-19, the hospital provides a dormitory for nurses while on duty and returns home during work holidays, although not all nurses are willing to live in the dormitory because they are separated from their families, especially children. "There is a dormitory with other nurses because the hospital already has these facilities, but my father has another house, so we live at his house" (P15). Nurses revealed that they tried to clean themselves before going home (P4 and P12), limiting social interaction with consideration for mutual comfort (P15). Restrictions on social interaction are carried out by nurses voluntarily, such as not visiting the mosque to worship with neighbors and advising extended families or relatives not to visit each other during the COVID-19 pandemic.

\section{Discussion}

\section{Nurses' psychological responses on COVID-19 pandemic}

The results of data analysis found themes about the various feelings of nurses due to COVID-19 in Indonesia. Positive feelings include surrendering to God about a pandemic condition, staying calm in facing this pandemic, and feeling support from various parties. On the other hand, nurses also feel fear, anxiety, and panic related to the increase in cases and deaths. The thing that nurses complained about was the patient's dishonesty in disclosing the symptoms of COVID-19 that they had, thus increasing the risk of transmission to nurses or other health workers. The conditions felt by nurses in Indonesia, may be experienced by nurses in other countries. 
Although there are not many comparisons that can be made regarding the feelings of nurses, especially in developing countries, research on the feelings and emotional responses of nurses and other health workers has been researched in Wuhan, China, Huang et al. (2020) found that the COVID-19 pandemic has been a source. Great pressure on individuals, or groups, including nurses. It was also explained that nurses in Anhui, China, have excessive anxiety and fear regarding the spread of COVID-19 [9]. The results of a cross-sectional study in Wuhan also found that $88.3 \%$ of staff in hospitals experienced psychological stress or emotional changes during their isolation period, and only $11.7 \%$ had no emotional changes. ${ }^{1}$, other research on the psychological impact of COVID-19 in China [10], [18]. The anxiety and fear of health workers in Wuhan, China, are related to the spread of disease and isolation, and similar psychological responses are found in other developed countries such as France and Germany [19], [20], [21], [22]. Nurses in Indonesia and in other countries who take care of COVID-19 patients experience fear and anxiety. On the other hand, they try to be calm and continue to serve patients.

The fear and various emotions felt by nurses in Indonesia, perhaps due to the increasing number of nurses who were infected and died during the COVID-19 pandemic. Data show that around 51-55 nurses in Indonesia died [2]. The trend of an increasing number of nurses infected with COVID-19 also occurs in the world. A total of 90,000 health workers worldwide are believed to have been infected with the virus, and perhaps, the number has increased several times now [2]. In addition, people's behavior in reacting to COVID-19 also increases the fear of nurses. Indonesian people in certain areas have a lack of awareness of the importance of preventing COVID-19 and the diagnosis process, as a result every day, there is media news about the forced taking of COVID-19 bodies by people from hospitals to take them home, family anger because they are separated from families sick, or anger because of waiting for a long PCR test result [23], [24], [25], [26]. These conditions may be related to the characteristics of people in developing countries, they are limited awareness of health, low level of knowledge, low economy, and have a strong belief in ancestral culture. This culture influences health behavior either positively or negatively [27], [28].

The Indonesian government has socialized the importance of preventing COVID-19, however, the data found that the use of masks is still below 70\% [29], the principles of physical distancing are violated [30], and held gathering activities, for example, wedding celebrations, which eventually gave rise to new clusters COVID-19 [31]. These behaviors are different from people in developed countries, related to discipline in preventing transmission [32]. The specific conditions about behavior and public awareness found in this study represent new views from nurses about society, and awareness of COVID-19 in developing and multicultural countries like Indonesia. Comparative research in other developing countries will enrich information about people's behavior about COVID-19, which will be useful in a social approach as one of the important things [33] in the prevention and management of pandemics.

This study also found the results of nurses' optimistic feelings, they continued to work professionally, by surrendering to God Almighty, health care during the pandemic was their duty, and feeling support from various parties. The concept of Caring and Altruism forms nurses to play a role in health care in any condition [34]. The attitude of nurses who continue to serve patients is based on the value of altruism which is the basis for professional nursing practice. Altruism is a nurse who puts the patient's interests ahead of their interests and cares for the welfare of others. On the other hand, strict and consistent government policies and regulations related to COVID-19 from various social and economic aspects, cross-sectoral synergy, and correct information about COVID-19 in media that is easily accessible to the public will accelerate the handling of COVID-19, and possibly reducing the anxiety, fear, and stigma experienced by nurses [38]. Altruism is a nurse who puts the patient's service ahead of their interests. On the other hand, firm and consistent policies of government regulations are needed concerning COVID-19 elimination actions from various aspects, including social, economic, cross-sectoral synergy, and information about COVID-19 from media that is easy to access. These actions would accelerate the handling of COVID-19 and may also have an impact on reducing the anxiety, fear, and stigma felt by nurses.

\section{behavior}

\section{COVID-19 effects on health awareness and}

The results of the study found expressions of nurses about changes in health behavior and awareness of nurses, other health workers in hospitals, families, and communities since the COVID-19 pandemic. Nurses perceive that awareness of working following SOPs is increasing in health workers, especially the use of PPE. Families and communities are aware of cleanliness. This may be because of information about transmission and death due to COVID-19 which is very high is widely spread in various print media, TV, and online media. This information has a positive or negative effect on society [34], [35]. Various parties such as professional organizations, hospital management, and the Indonesian Ministry of Health all reminded the importance of maintaining cleanliness and following SOPs for preventing transmission of COVID-19, as the hospital is a place of a high risk of transmission. Research at Zhongnan Hospital, Wuhan University of 103 health workers infected with COVID-19 found that most of them believed that they were infected with COVID-19 in hospitals (84.5\%), in laboratories (1.0\%), 
and communities (4.9\%) [1]. Changes in the health behavior of nurses and health workers in Indonesia may occur in other developing countries, but there is little evidence that explains this in international publications.

The results found that the government is improving various health facilities for handling COVID19 , although it is felt that it is not evenly distributed between hospitals in the capital and the regions. At the beginning of the pandemic, PPE was scarce and costly because the demand was suddenly increasing, there was panic buying, and limited stock in developing countries such as Indonesia [36]. This situation is inversely proportional to developed countries such as China which has patient rehabilitation centers for COVID-19 [37] and Singapore which has sufficient ventilators [35]. There is limited information about the scarcity of health facilities in developed countries, in contrast to developing countries with low economic conditions. However, limited information published about the actions and challenges of developing countries dealing with COVID-19, India, and Africa, are still struggling to cope with this pandemic [38], [39]. The improvement of facilities for COVID-19 services in Indonesia needs to be improved so that positive health behavior is maintained.

\section{nurses}

\section{The government actions in protecting}

The data analysis found government actions for the welfare of health workers such as services and protection, and nurses' expectations of the government. Nurses admit that there have been many government actions for them, but some have not yet been realized, such as limited PPE and incentives. Nurses also expect special access to health services, including for families. Nurses' expectations are reasonable because their responsibility as one of the frontlines in the COVID-19 service needs to be protected.

Provinces with high COVID-19 cases such as Jakarta, East Java, and West Java through their local governments have promised incentives for nurses at public hospitals [2]. Some of the incentives have been paid and some have not. The Indonesian government has developed a protection strategy, especially for health workers. These programs include providing a guest house for health workers while on duty, providing PPE from the government and various agencies, conducting free and periodic PCR/swab tests, providing vitamins and supplements, and incentives [40], and incentives [41].

Protection is also given to nurses and other health workers to prevent negative stigma from the community. The Indonesian government actions are in line with research on stigma against health workers in other countries [11], [42], [43], [44], [45]. The government carries out various protections for nurses at COVID-19 referral hospitals. However, nurses in Indonesia do not only work in COVID-19 referral hospitals, but there are also millions of nurses who work in $\mathrm{PHC}$, private hospitals, and clinics. They take care of the sick and the risk of contracting COVID-19 because they sometimes work with limited PPE facilities. Government policies and support for all nurses, especially in preventing the transmission of COVID-19, will be very significant for the protection of nurses.

\section{Conclusion}

Nurses' feelings due to the COVID-19 pandemic were explored in this study. The nurse informed about the uncomfortable psychological conditions during the COVID-19 pandemic, if this condition persists, it might have an impact on nurses' depression. Limited public knowledge about COVID-19 and strong cultural influences also affect the psychology of nurses, especially negative stigma. They also have perspectives that the Indonesian government continues to improve various health facilities to deal with COVID19 , but it faces many challenges. As a result, cases of morbidity and mortality are still fluctuating. A firm and consistent government policy regarding COVID-19 from various aspects is needed. Social aspects, crosssectoral cooperation, valid information to the public, and easy access to health services would accelerate the handling of COVID-19. This comprehensive policy would also increase the protection and productivity of health workers, including nurses. Further research on developing mental strengthening interventions for nurses would be useful for preventing stress and depression in nurses as the impact of COVID-19.

\section{Acknowledgment}

The authors' appreciation to all participants who volunteered to make this study possible.

\section{References}

1. World Health Organization. WHO Director-general's Opening Remarks at the Media Briefing on COVID-19. Geneva: World Health Organization; 2020. Available from: https://www.who. int/director-general/speeches/detail/who-director-generals-opening-remarks-at-the-media-briefing-on-covid-19---11march-2020. [Last accessed on 2020 Mar 11]. https://doi. org/10.1093/ww/9780199540884.013.u23682

2. Satuan Tugas Penanganan COVID 19. Peta Sebaran. Indonesia: Satuan Tugas Penanganan COVID 19; 2020. 
Available from: https://www.covid19.go.id/peta-sebaran. [Last accessed on 2020 Oct 29].

3. Centers for Disease Control and Prevention. Steps to Prevent Illness. USA: Centers for Disease Control and Prevention; 2020 Available from: https://www.cdc.gov/coronavirus/2019-ncov/ about/prevention. [Last accessed on 2020 Sep 29]. https://doi. org/10.1093/ofid/ofv131.60

4. Kementerian Kesehatan RI. Tentang Novel Coronavirus (NCOV). Jakarta: Kementerian Kesehatan Rl; 2020. Available from: https://www.kemkes.go.id/article/view/20012900002/ Kesiapsiagaan-menghadapi-Infeksi-Novel-Coronavirus. [Last accessed on 2020 Sep 29].

5. Kementerian Kesehatan RI. Cegah nCoV, Kemenkes Siagakan Termoscanner di 135 Pintu Negara. Jakarta: Kementerian Kesehatan RI; 2020a. Available from: https://www.kemkes.go.id/ article/view/20012100002/cegah-ncov-kemenkes-siagakantermoscanner-di-135-pintu-negara. https://doi.org/10.32922/ jkp.v8i1. [Last accessed on 2020 Sep 29].

6. Kementerian Kesehatan RI. Pasien Positif Covid-19 Menjadi 19 Orang, Kemenkes Fokus Pada Tracing dan Tracking Contact. Jakarta: Kementerian Kesehatan Rl; 2020b. Available from: https://www.kemkes.go.id/article/view/20030900003/pasienpositif-covid-19-menjadi-19-orang-kemenkes-fokus-padatracing-dan-tracking-contact. [Last accessed on 2020 Sep 29]. https://doi.org/10.32922/jkp.v8i2.290

7. Kementerian Kesehatan RI. Keputusan Menteri Kesehatan Republik Indonesia Nomor HK.01.07/MENKES/169/2020 Tentang Penetapan Rumah Sakit Rujukan Penanggulangan Penyakit Infeksi Emerging Tertentu. Jakarta: Kementerian Kesehatan RI; 2020c. Available from: https://www.kemkes. go.id/article/view/20012900002/Kesiapsiagaan-menghadapiInfeksi-Novel-Coronavirus. [Last accessed on 2020 Sep 29]. https://doi.org/10.31219/osf.io/gwrbh

8. CNN Indonesia. Kisah Pilu dari Penolakan Jenazah Perawat Corona di Semarang. Jakarta: CNN Indonesia; 2020a. Available from: https://www.cnnindonesia.com/ nasional/20200410174518-20-492451/kisah-pilu-daripenolakan-jenazah-perawat-corona-di-semarang. accessed on 2020 Nov 01]. https://doi.org/10.35497/326

9. Huang L, Xu F, Liu H. Emotional responses and coping strategies of nurses and nursing college students during COVID-19 outbreak. BMJ Yale. 2020;15(8):e0237303. https:// doi.org/10.1371/journal.pone.0237303

PMid:32764825

10. Jin $Y H$, Huang $Q$, Wang $Y Y$, Zeng $X T$, Luo LS, Pan ZY, et al. Perceived infection transmission routes, infection control practices, psychosocial changes, and management of COVID19 infected healthcare workers in a tertiary acute care hospital in Wuhan: A cross-sectional survey. Mil Med Res. 2020;7(1):24. https://doi.org/10.1186/s40779-020-00254-8

PMid:32393381

11. Prasad SK, Karahda A, Singh P, Gupta R. Role of mental health professionals in dealing with the stigma attached to COVID-19. Gen Psychiatr. 2020;33(5):e100298. https://doi.org/10.1136/ gpsych-2020-100298

PMid:32908960

12. Sandelowski M. What's in a name? Qualitative description revisited. Res Nurs Health. 2010;33(1):77-84. https://doi. org/10.1002/nur.20362

13. Kim H, Sefcik JS, Bradway C. Characteristics of qualitative descriptive studies: A systematic review. Res Nurs Health. 2017;40(1):23-42. https://doi.org/10.1002/nur.21768

14. Doyle L, McCabe C, Keogh B, Brady A, McCann M. An overview of the qualitative descriptive design within nursing research. J Res Nurs. 2019;25(5):443-55. https://doi. org/10.1177/1744987119880234

15. Carter N, Bryant-Lukosius D, DiCenso A, Blythe J, Neville AJ.
The use of triangulation in qualitative research. Oncol Nurs Forum. 2014;41(5):545-7.

PMid:25158659

16. Widiasih R, Nelson K. Muslim husbands' roles in women's health and cancer: The perspectives of muslim women in Indonesia. Asian Pac J Cancer Prev. 2018;19(6):1703-9.

PMid:29938469

17. Polit DF, Beck C. Essentials of Nursing Research. $8^{\text {th }}$ ed. Philadelphia, PA: Wolters Kluwer; 2014.

18. Mo $Y$, Deng $L$, Zhang $L$, Lang $Q$, Liao $C$, Wang $N$, et al. Work stress among Chinese nurses to support Wuhan in fighting against COVID-19 epidemic. J Nurs Manag. 2020;28(5):10021009. https://doi.org/10.1111/jonm.13014 PMid:32255222

19. Kang L, Ma S, Chen M, Yang J, Wang Y, Li R, et al. Impact on mental health and perceptions of psychological care among medical and nursing staff in Wuhan during the 2019 novel coronavirus disease outbreak: A cross-sectional study. Brain Behav Immun. 2020;87:11-7. https://doi.org/10.1016/j. bbi.2020.03.028

PMid:32240764

20. El-Hage W, Hingray C, Lemogne C, Yrondi A, Brunault P, Bienvenu $\mathrm{T}$, et al. Health professionals facing the coronavirus disease 2019 (COVID-19) pandemic: What are the mental health risks? Encephale. 2020;46(3s):S73-80.

PMid:32370984

21. Walton ME, Murray E, Christian MD. Mental health care for medical staff and affiliated healthcare workers during the COVID-19 pandemic. Eur Heart J Acute Cardiovasc Care. 2020;9(3):241-7. https://doi.org/10.1177/2048872620922795 PMid:32342698

22. Elbay RY, Kurtulmuş A, Arpacıoğlu S, Karadere E. Depression, anxiety, stress levels of physicians and associated factors in Covid-19 pandemics. Psychiatry Res. 2020;290:113130. https:// doi.org/10.1016/j.psychres.2020.113130

PMid:32497969

23. Aky. Jenazah Bocah Reaktif Covid-19 Dibawa Paksa Keluarga Naik Motor. Jakarta: Okezone.com; 2020. Available from: https://www.news.okezone.com/read/2020/09/01/340/2271113/ jenazah-bocah-reaktif-covid-19-dibawa-paksa-keluarga-naikmotor. [Last accessed on 2020 Sep 29]. https://doi.org/10.33474/ yur.v3i2.6745

24. Iswara. Keluarga Ambil Paksa Jenazah Covid-19 hingga Pukul Tenaga Medis, Kesal dengan Perlakuan Pihak RS. Jakarta: Tribun News; 2020. Available from: https://wwww.newsmaker. tribunnews.com/2020/06/28/keluarga-ambil-paksa-jenazahcovid-19-hingga-pukul-tenaga-medis-kesal-dengan-perlakuanpihak-rs?page $=4$. [Last accessed on 2020 Sep 29]. https://doi. org/10.52160/ejmm.v4i10.474

25. Oleribe EO, Alasia DD. Culture and health: The effect of Nupe cultural practice on the health of Nupe people. Niger $\mathrm{J}$ Med. 2006;15(3):325-8. https://doi.org/10.4314/njm.v15i3.37241 PMid:17111771

26. Rassjo EB, Kiwanuka R. Views on social and cultural influence on sexuality and sexual health in groups of Ugandan adolescents. Sex Reprod Healthc. 2010;1(4):157-62. https://doi. org/10.1016/j.srhc.2010.08.003

PMid:21122615

27. Alam SO. Satgas COVID-19: Kepatuhan Warga Pakai Masker di Bawah 70 Persen. Jakarta: Detik; 2020. Available from: https:// www.health.detik.com/berita-detikhealth/d-5152510/satgascovid-19-kepatuhan-warga-pakai-masker-di-bawah-70-persen. [Last accessed on 2020 Sep 29]. https://doi.org/10.33021/exp. v3i2.1251

28. Herlambang AA. Bupati Blora Asyik Joget di Hajatan Tanpa 
Masker Bikin Warga Geram. Semarang: Ayo Semarang; 2020. Available from: https://www.ayosemarang.com/ $\mathrm{read} / 2020 / 10 / 13 / 65243 /$ bupati-blora-asyik-joget-di-hajatantanpa-masker-bikin-warga-geram. [Last accessed on 2020 Sep 29].

29. Alam SO. Ratusan Orang Terinfeksi Corona dari Klaster Resepsi Pernikahan. Jakarta: Detik; 2020b. Available from: https://www. health.detik.com/berita-all/d-5162425/ratusan-orang-terinfeksicorona-dari-klaster-resepsi-pernikahan. [Last accessed on 2020 Sep 29].

30. Dupuy B. Posts Misrepresent CDC Study Examining Mask Use. London: AP News; 2020. Available from: https://www.apnews. com/article/fact-checking-afs: Content:9573390682. [Last accessed on 2020 Oct 16].

31. Kaushik M, Agarwal D, Gupta AK. Cross-sectional study on the role of public awareness in preventing the spread of COVID-19 outbreak in India. Postgrad Med J. 2020. https://doi.org/10.1136/ postgradmedj-2020-138349.

32. Giuffra JM. Altruism is the heart of our story. Nursing Outlook. 2020;61(2):67-9. https://doi.org/10.1016/j.outlook.2012.10.005

33. Ahmad AR, Murad HR. The impact of social media on panic during the COVID-19 pandemic in Iraqi Kurdistan: Online questionnaire study. J Med Internet Res. 2020;22(5):e19556. https://doi.org/10.2196/19556

34. Sahni $H$, Sharma $H$. Role of social media during the COVID-19 pandemic: Beneficial, destructive, or reconstructive? Int J Acad Med. 2020;6:70-5. https://doi.org/10.1186/s13054-020-2814-x

35. Liew MF, Siow WT, MacLaren G, See KC. Preparing for COVID-19: Early experience from an intensive care unit in Singapore. Crit Care.2020;24(1):83.

PMid:32151274

36. World Health Organization. Shortage of Personnel Protective Equipment Endangering-Health Workers Worldwide. Geneva: World Health Organization; 2020. Available from: https:// www.who.int/news/item/03-03-2020-shortage-of-personalprotective-equipment-endangering-health-workers-worldwide. [Last accessed on 2020 Sep 29]. https://doi.org/10.26616/ nioshpub2009106

37. Li J. Rehabilitation management of patients with COVID-19: Lessons learned from the first experience in China. Eur $J$ Phys Rehabil Med. 2020;56(3):335-8. https://doi.org/10.23736/ s1973-9087.20.06292-9
PMid:32329589

38. Garg S, Basu S, Rustagi R, Borle A. Primary health care facility preparedness for outpatient service provision during the COVID-19 pandemic in India: Cross-sectional study. JMIR Public Health Surveill. 2020;6(2):e19927. https://doi. org/10.2196/preprints. 19927

PMid:32452819.

39. Mayhew S, Gray G, Fairlie L, Eichbaum Q, Mayhew S, Allwood B, et al. COVID-19 in Africa: Care and protection for frontline healthcare workers. Global Health. 2020;16(1):46.

PMid:32414379

40. Kementerian Kesehatan RI. Pedoman Pencegahan dan Penanganan COVID-19 Revisi 5. Jakarta: Kementerian Kesehatan Rl; 2020. Available from: https://www.covid19. kemkes.go.id/protokol-COVID-19/kmk-no-hk-01-07-menkes413-2020-ttg-pedoman-pencegahan-dan-PenangananCOVID-19/\#.X3colNkzZdg. [Last accessed on 2020 Sep 29]. https://doi.org/10.22236/jmbp.v1i1.5708

41. Kominfo RI. Inilah Besaran Insentif Tenaga Kesehatan Tangani COVID-19. Jakarta: Kominfo RI; 2020. Available from: https://www.kominfo.go.id/content/detail/26181/inilahbesaran-insentif-tenaga-kesehatan-tangani-COVID-19/0/berita. [Last accessed on 2020 Nov 01]. https://doi.org/10.23917/ jk.v11i2.7536

42. Chopra KK, Arora VK. Covid-19 and social stigma: Role of scientific community. Indian J Tuberc. 2020;67(3):284-5. https:// doi.org/10.1016/j.ijtb.2020.07.012

PMid:32825854

43. Bagchi S. Stigma during the COVID-19 pandemic. Lancet Infect Dis. 2020;20(7):782.

PMid:32592670

44. Hashmi FK, Iqbal Q, Haque N, Saleem F. Religious cliché and stigma: A brief response to overlooked barriers in COVID-19 management. J Relig Health. 2020;59(6):2697-700.

PMid:32643082

45. Uvais NA, Shihabudheen P, Hafi NA. Perceived stress and stigma among doctors working in COVID-19-designated hospitals in india. Prim Care Companion CNS Disord. 2020;22(4)2724. https://doi.org/10.4088/pcc.20br02724.

PMid:32731315 